\title{
PENGARUH BEBAN KERJA, LINGKUNGAN KERJA, DAN DUKUNGAN SOSIAL TERHADAP BURNOUT PUSTAKAWAN DI KOTA MATARAM
}

\author{
Lalu Ciptadi Romadhoni*, Thatok Asmony**, Mukmin Suryatni**
}

Pengutipan: Romadhoni, L. C., Asnomy T., \& Suryatni, M. (2015). Pengaruh beban kerja, lingkungan kerja, dan dukungan sosial terhadap burnout pustakawan di Kota Mataram. Jurnal Ilmu Perpustakaan, Informasi, dan Kearsipan Khizanah Al-Hikmah, 3(2), 125-145.

* Mahasiswa Program Magister Manajemen Pascasarjana Universitas Mataram.

** Dosen Program Magister Manajemen Pascasarjana Universitas Mataram.

ABSTRAK
Penelitian ini bertujuan untuk mengetahui dan menganalisis efek dari kelebihan beban kerja,
lingkungan kerja, dan dukungan sosial terhadap aktifitas layanan pustakawan di Kota
Mataram. Responden pada penelitian ini adalah 76 pustakawan yang bekerja di Perpustakaan
Umum Kota Mataram. Analisis data dengan menggunakan teknik multiple linear regression.
Hasil penelitian ini menunjukkan bahwa beban kerja secara positif dan signifikan dapat
memberikan efek perasaan stres kepada semua responden, namun lingkungan kerja dan
dukungan masyarakat tidak terlalu memberikan dampak stres kepada mereka. Secara
keseluruhan ketiga unsur tersebut dapat memberikan efek lelah, yang berujung pada stres
pada pekerjaan. Implikasi dari penelitian ini diharapkan dapat menyediakan masukan dan
informasi yang bermanfaat kepada unsur pimpinan (manajemen) di Perpustakaan Umum Kota
Mataram dalam usahanya mengambil kebijakan yang berkenaan dengan hal ini.
Kata Kunci: Beban kerja pustakawan, lingkungan kerja
The objective of the research is to know and analyze the effect of workload, working environment, and
social support toward burnout of librarian at Mataram City. Respondents of this research were 76
librarian of public library at Mataram City. The data was analyzed using multyple linear regression.
The result of this research indicates that workload have partially positive and significant effect toward
burnout of librarian, instead working environment and social support have partially negative and
significant effect toward burnout of librarian. Workload, working environment, and social support have
simultantly significant effect toward burnout of librarian at Mataram City. The result of this research is
expected to provide input and information for management of public library at Mataram City in order to
making decision to decrease burnout level oflibrarian.
Key Words: Workload, Working Environment




\section{PENDAHULUAN}

Perpustakaan sebagai salah satu garda terdepan dalam peningkatan kualitas sumber daya manusia melalui penyediaan koleksi bahan pustaka dan non pustaka sebagai sumber belajar, sumber informasi, dan ilmu pengetahuan memilki peran strategis dalam pelaksanaan pembangunan kualitas Sumber Daya Manusia (SDM) menuju peningkatan Indeks Prestasi Manusia (IPM) Indonesia pada umumnya dan NTB pada khususnya.

Kota Mataram sebagai ibukota provinsi sekaligus sebagai pusat pemerintahan dan pusat pendidikan menjadi barometer keberhasilan peningkatan kualitas SDM di wilayah Provinsi NTB. Perhatian khusus diberikan kepada masyarakat pelajar tingkat SD/MI sebagai tahapan awal pembentukan budaya minat baca masyarakat menuju masyarakat sadar informasi.

Profesi pustakawan belum begitu dikenal luas di tengah masyarakat, banyak pihak yang beranggapan bahwa orang yang bekerja di perpustakaan adalah pustakawan. Anggapan tersebut tidak sepenuhnya salah, memang kenyataannya masih banyak petugas perpustakaan atau tenaga teknis perpustakaan yang bukan pustakawan. Tetapi hal ini juga perlu diluruskan bahwa pustakawan dengan petugas perpustakaan itu berbeda. "Pustakawan adalah seseorang yang memiliki kompetensi yang diperoleh melalui pendidikan dan/atau pelatihan kepustakawanan serta mempunyai tugas dan tanggung jawab untuk melaksanakan pengelolaan dan pelayanan perpustakaan" (Undang-undang Republik
Indonesia Nomor 43 Tahun 2007 tentang Perpustakaan dalam Pasal 1 Ayat 8).

Pekerjaan rutin yang dijalani oleh seorang pustakawan sangat berpotensi menjadi penyebab stress. Hari-hari kerja normal seorang pustakawan apapun jenis perpustakaannya, selalu dipenuhi dengan interupsi, baik dari pengguna, sesama karyawan, maupun atasan yang potensial menjadi penyebab stress. Interupsi yang dialamatkan kepada pustakawan lebih banyak diterima oleh pustakawan yang bertanggung jawab untuk pemberian layanan.

Beberapa tokoh psikologi mengemukakan bahwa stress dalam bekerja (job stress) dapat terjadi pada pekerjaan layanan sosial (social service atau helping profession), yaitu umumnya profesi yang memberikan perhatian pada kesejahteraan orang lain yang secara umum mengarah pada profesi layanan seperti perawat, dokter, guru, dan pekerja pemberi informasi layanan umum lainnya (Caputo, 1991). Menurut Cherniss (1980) pekerjaan pustakawan dapat dikatakan juga sebagai pekerjaan layanan sosial, karena pustakawan bertugas untuk memberikan layanan informasi kepada pengguna yang datang ke perpustakaan.

Burnout ternyata juga dapat terjadi pada pustakawan (Hariyadi, 2006). Burnout di perpustakaan adalah kelelahan yang disebabkan oleh intensitas kerja pustakawan. Mereka bekerja terlalu banyak dan terlalu lama, sehingga tanpa mereka sadari, mereka "mengabaikan" kebutuhan dan keinginan mereka sebagai individu, mereka merasakan adanya tekanan untuk memberi lebih banyak dan lebih banyak lagi. Tekanan ini bisa berasal dari dalam diri mereka sendiri, dari pimpinan, dalam konteks perpustakaan 
sebagai layanan umum, dan tekanan yang signifikan berasal dari pengguna (Caputo, 1991). Adanya tuntutan ini dapat menimbulkan perasaan bersalah karena tidak bisa memenuhinya yang kemudian mendorong mereka untuk menambah energi lebih banyak dan lebih besar dalam upaya untuk memenuhi kebutuhan pengguna tersebut (Fraudenberger, 1974 dalam Poerwandari, 2010).

Berdasarkan penelitian yang dilakukan Fatmawati (2012) pada staf perpustakaan bagian layanan di Badan Perpustakaan dan Arsip Daerah (BPAD) Provinsi DKI Jakarta menunjukkan tingkat burnout sebanyak $62 \%$ dimana $7 \%$ dari responden dinyatakan positif teridentifikasi mengalami burnout pada level tinggi. Dengan demikian potensi burnout juga dapat terjadi pada pustakawan di Kota Mataram.

Pustakawan memiliki beban kerja dengan intensitas yang beragam dan membutuhkan kesabaran dalam melaksanakan pekerjaannya, dikarenakan pekerjaan ini mengharuskan mereka untuk melayani dan memberikan kepuasan kepada pemustaka ditambah lagi untuk menyelesaikan pekerjaannya terkadang harus dilakukan di luar jam kerja. Selain itu pencapaian target pengolahan bahan pustaka dan layanan dalam jumlah dan kurun waktu tertentu juga memberikan tekanan kepada pustakawan. Mencapai target dalam jumlah dan waktu yang telah ditentukan serta melayani pemustaka dengan kualitas prima merupakan tuntutan dari lembaga yang menjadi beban kerja tersendiri bagi pustakawan.

Adapun lingkungan kerja pada lembaga perpustakaan yaitu penerangan yang cukup, suhu udara yang nyaman karena terpasang pendingin ruangan yang cukup, sirkulasi udara cukup baik karena tersedianya ventilasi, ukuran ruang kerja yang sesuai dengan kebutuhan, privasi ruang kerja yang terjamin, setiap bagian ruangan terlihat bersih dan rapi, peralatan kantor lengkap sesuai kebutuhan, serta keamanan kerja yang difasilitasi dengan penggunaan security dan CCTV. Tidak semua kriteria yang tersebut di atas dapat terpenuhi oleh seluruh lembaga perpustakaan yang berada di wilayah Kota Mataram, sehingga kontradiksi antara kondisi ideal dengan fakta di lapangan juga dapat menjadi pemicu munculnya burnout pada pustakawan.

Menurut Sarafino (2006) kehadiran pasangan dan feedback positive yang diberikan oleh atasan merupakan bagian dari jenis-jenis dukungan sosial. Dukungan sosial merujuk pada kenyamanan, kepedulian, harga diri, atau segala bentuk bantuan lainnya yang diterima dari orang lain atau kelompok. Oleh karena itu, adanya dukungan sosial membuat individu merasa yakin bahwa dirinya dicintai, dihargai sehingga dapat mengurangi gejala burnout yang dialaminya. Sebaliknya, tidak adanya dukungan sosial dapat menimbulkan ketegangan dan meningkatkan terjadinya burnout pada individu (Purba, 2007 : 78).

Beban kerja dengan intensitas yang beragam serta lingkungan kerja yang tidak kondusif dapat menimbulkan potensi burnout pada pustakawan. Hal ini terlihat dari gejala burnout pada pustakawan di Kota Mataram yang ditunjukkan seperti kurang peduli terhadap pemustaka, cenderung pasif, mudah lelah, sakit-sakitan, sering menunda pekerjaan, menghindari pekerjaan, dan bahkan absen dari pekerjaan. Burnout pada pustakawan dapat menyebabkan menurunnya produktivitas kerja yang tentunya 
berpengaruh pada kinerja lembaga perpustakaan. Keadaan ini dapat menjadi semakin parah apabila seorang pustakawan tidak mendapat dukungan sosial yang memadai baik dari pihak rekan sekerja, atasan, bahkan organisasi atau lembaga perpustakaan. Kurangnya pengakuan prestasi, dukungan secara emosional, persetujuan gagasan, dan bantuan fisik dapat membuat seorang pustakawan merasa frustasi ketika telah melakukan pekerjaan secara maksimal tetapi tidak mendapat apresiasi yang cukup, kesenjangan antara tuntutan yang melebihi kemampuan dan sumber daya individu dengan minimnya dukungan sosial dapat memicu pustakawan mengalami burnout.

Fenomena di atas merupakan salah satu alasan yang menarik untuk dilakukan penelitian mengenai pengaruh dari beban kerja, lingkungan kerja, dan dukungan sosial terhadap burnout pustakawan di Kota Mataram.

\section{TUJUAN PENELITIAN}

Berdasarkan fokus penelitian yang telah dirumuskan, maka tujuan dari penelitian ini adalah:

a) Untuk mengetahui apakah beban kerja, lingkungan kerja, dan dukungan sosial berpengaruh signifikan secara simultan terhadap Burnout pustakawan di Kota Mataram.

b) Untuk mengetahui apakah beban kerja, lingkungan kerja, dan dukungan sosial berpengaruh signifikan secara parsial terhadap burnout pustakawan di Kota Mataram.

c) Untuk mengetahui variabel manakah yang mempunyai pengaruh paling dominan terhadap burnout pustakawan di Kota Mataram.

\section{KAJIAN LITERATUR}

Purba, J., Yulianto, A., \& Widyanti, E. (2007) meneliti tentang pengaruh dukungan sosial terhadap burnout pada guru. Hasil penelitian menunjukkan bahwa dukungan sosial berpengaruh negatif dan signifikan terhadap burnout pada guru, artinya semakin besar dukungan sosial yang diperoleh akan mengurangi level burnout yang dialami guru.

Khotimah, K. (2010) meneliti tentang hubungan antara persepsi terhadap lingkungan kerja psikologis dengan burnout pada perawat RSU Budi Rahayu Pekalongan. Hasil penelitian menunjukkan bahwa terjadi hubungan yang negative dan signifikan terhadap lingkungan kerja psikologis dengan burnout, artinya semakin negative persepsi terhadap lingkungan kerja psikologis maka semakin tinggi burnout.

Maharani, P.A. (2012) meneliti tentang hubungan kejenuhan kerja (burnout) dengan kinerja perawat dalam pemberian asuhan keperawatan. Hasil penelitian menunjukkan bahwa sebagian besar responden mengalami kejenuhan kerja ringan dan sebagian besar responden memiliki kinerja dalam pemberian asuhan keperawatan yang baik.

Fatmawati, R. (2012) meneliti tentang hubungan antara faktor internal (jenis kelamin, status perkawinan, usia, pendidikan, dan jam kerja) dan faktor eksternal (lingkungan kerja) terhadap tingkat burnout pada staf perpustakaan bagian layanan BPAD Provinsi DKI Jakarta. Hasil penelitian menunjukkan 
bahwa terdapat hubungan yang positif dan signifikan antara factor internal dan eksternal terhadap tingkat burnout pada staf perpustakaan bagian layanan BPAD Provinsi DKI Jakarta.

Wulandari, S. A. (2013) meneliti tentang hubungan persepsi dukungan sosial rekan kerja terhadap burnout pada teller bank. Hasil penelitian menunjukkan bahwa terdapat hubungan negatif yang sangat signifikan antara persepsi dukungan sosial rekan kerja dengan burnout pada teller bank.

\section{TINJAUAN TEORETIS}

\section{a. Burnout}

Fraudenberger (1973) mengartikan burnout sebagai kelelahan mental, kehilangan komitmen, dan penurunan motivasi pada diri pekerja (Ilyas, 2012:2). Sedangkan menurut Chavalitsakulchai dan Shahvanaz (1991) dalam Setyawati (2010) burnout atau kelelahan kerja merupakan fenomena yang kompleks yang disebabkan oleh faktor biologi pada proses kerja serta dipengaruhi oleh faktor eksternal maupun internal. Faktor eksternal pengaruh terjadinya kelelahan kerja yaitu lingkungan kerja yang tidak memadai, dan internal pengaruh kelelahan kerja yaitu masalah psikososial (Setyawati, 2010). Kelelahan kerja menunjukkan keadaan yang berbeda-beda tetapi semuanya berkaitan kepada pengurangan kapasitas kerja dan ketahanan umum (Wijaya \& Setyawati, 2006 dalam Kurniawati, 2012 : 163).

Semua pekerjaan akan menghasilkan kelelahan kerja, dan kelelahan kerja akan menurunkan kinerja serta menambah tingkat kesalahan kerja (Nurmianto, 1996). Setiap orang yang bekerja dengan melebihi batas tertentu akan menimbulkan kelelahan, oleh karena itu setiap perusahaan haruslah memikirkan waktu istirahat sebelum tenaga pulih kembali (Nitisemito, 1996). Menurut Setyowati (2010), faktor-faktor yang dapat mempengaruhi terjadinya kelelahan kerja terdiri dari faktor lingkungan kerja yang tidak memadai untuk bekerja dan masalah psikososial mereka ataupun fisik mereka. Menurut Leither dan Maslach (2005) stress berkepanjangan yang dialami individu yang pekerjaannya berhadapan secara langsung dengan manusia sebagai penerima pelayanan disebut dengan istilah burnout.

Dengan demikian maka dapat disimpulkan bahwa yang dimaksud dengan burnout adalah suatu kondisi kelelahan fisik dan mental yang dialami oleh pekerja yang berhadapan langsung dengan manusia sebagai penerima pelayanan yang disebabkan oleh tingginya beban kerja, lingkungan kerja yang tidak memadai, masalah psikologis ataupun fisik pekerja.

Dalam artikel Smith, Gill dan Segal (2011) menuliskan bahwa gejala burnout secara umum adalah:

1) Gejala Fisik

$\checkmark$ Merasa lelah dan terkuras oleh waktu.

Menurunnya kekebalan tubuh, sering sakit-sakitan seperti sakit kepala, nyeri punggung, nyeri otot, flu, dan lain sebagainya.

$\checkmark$ Perubahan nafsu makan atau tidur.

2) Gejala Emosional

$\checkmark$ Merasa gagal dan selalu ragu dengan kemampuan

$\checkmark$ Merasa tidak berdaya dan kurang semangat

$\checkmark$ Kehilangan motivasi

$\checkmark$ Semakin sinis dan berfikir negatif

$\checkmark$ Penurunan kepuasan kerja

3) Perilaku 
Lari dari tanggung jawab

Menunda-nunda waktu lebih lama untuk menyelesaikan sesuatu

$\checkmark$ Menggunakan obat-obatan dan alkohol untuk mengatasinya

$\checkmark$ Frustasi

\section{b. Beban Kerja}

Beban kerja pustakawan meliputi jam kerja yang panjang dan banyaknya individu yang harus dilayani menyebabkan pustakawan merasa mempunyai beban kerja yang harus dipikul. Hal ini merupakan faktor pemicu stress yang potensial menjadi penyebab burnout pada pustakawan (Leither dan Maslach, 2005).

Beban kerja dapat berupa beban kerja fisik dan beban kerja psikologis. Beban kerja fisik dapat berupa beratnya pekerjaan seperti mengangkat, merawat mendorong. Sedangkan beban kerja psikologis dapat berupa sejauh mana tingkat keahlian dan prestasi kerja yang dimiliki individu dengan individu lainnya. Beban kerja yang dialami oleh seorang pustakawan dapat berupa tuntutan kerja yang tinggi, kurangnya pekerjaan dari hal-hal yang menarik dan menantang, dan pekerjaan yang kurang variatif/monoton. Beban kerja juga dapat diartikan sebagai kemampuan tubuh pekerja dalam menerima pekerjaan. Dari sudut pandang ergonomi, setiap beban kerja yang diterima seseorang harus sesuai dan seimbang terhadap kemampuan fisik maupun psikologis pekerja yang menerima beban kerja tersebut (Manuaba, 2000).

Lysaght et al (1989) membagi tiga kategori besar dari definisi beban kerja, yaitu:
1) Banyaknya pekerjaan dan hal yang harus dilakukan

2) Waktu maupun aspek-aspek tertentu dari waktu yang harus diperhatikan oleh pekerja, dan

3) Pengalaman psikologis subjektif yang dialami oleh seorang pekerja.

Menurut Gopher dan Doncin (dalam Lysaght et al, 1989) beban kerja diartikan sebagai suatu konsep yang timbul akibat adanya keterbatasan kapasitas dalam memproses informasi saat menghadapi suatu tugas, individu diharapkan dapat menyelesaikan tugas tersebut pada suatu tingkat tertentu.

Berdasarkan definisi di atas, maka dapat ditarik kesimpulan bahwa beban kerja merupakan sejauh mana kapasitas individu pekerja dibutuhkan dalam menyelesaikan tugas yang diberikan kepadanya yang dapat diindikasikan dari jumlah pekerjaan yang harus dilakukan, waktu/batasan waktu yang dimiliki oleh pekerja dalam menyelesaikan tugasnya, serta pandangan subjektif individu tersebut mengenai pekerjaan yang diberikan kepadanya.

Adapun faktor-faktor yang mempengaruhi beban kerja dalam penelitian Soleman (2011) adalah sebagai berikut:

1) Faktor eksternal yaitu beban yang berasal dari luar tubuh pekerja, seperti:

$\checkmark$ Tugas (Task). Meliputi tugas bersifat fisik seperti, stasiun kerja, tata ruang tempat kerja, kondisi ruang kerja, kondisi lingkungan kerja, sikap kerja, cara angkut, beban yang diangkat. Sedangkan tugas yang bersifat mental meliputi, tanggung jawab, 
kompleksitas pekerjaan, emosi pekerja dan sebagainya.

$\checkmark$ Organisasi Kerja. Meliputi lamanya waktu kerja, waktu istirahat, shift kerja, sistem kerja dan sebagainya.

$\checkmark$ Lingkungan Kerja. Lingkungan kerja ini dapat memberikan beban tambahan yang meliputi, lingkungan kerja fisik, lingkungan kerja kimiawi, lingkungan kerja biologis dan lingkungan kerja psikologis.

2) Faktor internal adalah faktor yang berasal dari dalam tubuh akibat dari reaksi beban kerja eksternal yang berpotensi sebagai stresor, meliputi faktor somatic (jenis kelamin, umur, ukuran tubuh, status gizi, kondisi kesehatan, dan sebagainya), dan faktor psikis (motivasi, persepsi, kepercayaan, keinginan, kepuasan, dan sebagainya).

\section{c. Lingkungan Kerja}

Nitisemito (2004) mengartikan lingkungan kerja adalah sesuatu yang ada di sekitar para pekerja dan dapat mempengaruhi dirinya dolam menjalankan tugas-tugas yang dibebankan. Sedangkan menurut Ahyari (1994) dalam Fatmawati (2012) lingkungan kerja adalah suatu tempat dimana para karyawan melakukan pekerjaannya.

Lingkungan kerja terdiri dari lingkungan fisik dan lingkungan non fisik. Lingkungan kerja menjadi salah satu pertimbangan bagi seseorang dalam memiliki pekerjaan, sekalipun nanti gaji yang akan diberikan terlalu besar, tetapi jika lingkungan kerjanya tidak menyenangkan, maka karyawan akan berfikir dua kali untuk menerima atau menolak pekerjaan tersebut, karena mungkin lingkungan dimana karyawan berada akan menghambat pekerjaan yang dilakukan. Oleh karena itu lingkungan kerja menjadi salah satu pertimbangan bagi seseorang didalam memiliki pekerjaan.

Dengan demikian dapat disimpulkan bahwa yang dimaksud dengan lingkungan pekerjaan adalah suatu tempat dimana karyawan melaksanakan pekerjaannya ataupun segala sesuatu yang ada di sekitar karyawan yang dapat mempengaruhi dirinya dalam melakukan pekerjaan yang dibebankan padanya.

Nitisemito (1996: 159) menyatakan bahwa lingkungan kerja diukur melalui indikator sebagai berikut yaitu:

1) Suasana kerja. Setiap karyawan selalu menginginkan suasana kerja yang menyenangkan, suasana kerja yang nyaman itu meliputi cahaya/penerangan yang jelas, suara yang tidak bising dan tenang, dan keamanan di dalam bekerja.

2) Hubungan dengan rekan kerja. Hal ini dimaksudkan hubungan dengan rekan kerja yang harmonis dan tanpa adanya intrik di antara sesama rekan kerja. Salah satu faktor yang dapat mempengaruhi karyawan tetap tinggal dalam suatu organisasi adalah adanya hubungan yang harmonis di antara rekan kerja. Hubungan rekan kerja yang harmonis dan kekeluargaan merupakan salah satu faktor yang dapat mempengaruhi kinerja karyawan.

3) Tersedianya fasilitas kerja. Hal ini dimaksudkan bahwa peralatan yang digunakan untuk mendukung kelancaran kerja lengkap/mutakhir. Tersedianya fasilitas kerja yang lengkap, walaupun tidak baru 
merupakan salah satu penunjang proses kelancaran dalam bekerja.

\section{d. Dukungan Sosial}

$\begin{aligned} & \text { Dukungan } \\ & \text { didefinisikan } \\ & \text { berdasarkan }\end{aligned}$ pada
banyaknya kehadiran individu yang
memberikan dukungan sosial. Kemudian
definisi ini berkembang sehingga definisi
dukungan sosial tidak hanya meliputi
banyaknya teman yang menyediakan
dukungan sosial, tetapi termasuk juga
kepuasan terhadap dukungan yang
diberikan (Sarason et al dalam Ogden,
2004).

Istilah "dukungan sosial" secara umum digunakan untuk mengacu pada penerimaan rasa aman, peduli, penghargaan atau bantuan yang diterima seseorang dari orang lain atau kelompok. Berikut kutipannya : "Social support is generally used to refer to the perceived comfort, caring, esteem or help a person receives from other people or groups" (Sarafino, 2006). Dukungan sosial tersebut dapat datang dari sumber-sumber yang berbeda, seperti dari teman, rekan sekerja, atasan, atau anggota organisasi. Dengan adanya dukungan sosial dari berbagai sumber, individu akan merasa yakin bahwa dirinya dicintai dan disayangi, dihargai, bernilai dan menjadi bagian dari jaringan sosial.

Dengan demikian dapat disimpulkan bahwa yang dimaksud dengan dukungan sosial dalam penelitian ini adalah penerimaan rasa aman, peduli, penghargaan atau bantuan yang diterima seorang karyawan dari rekan kerja ataupun atasannya.

Sarafino (2006) mengungkapkan pada dasarnya ada lima jenis dukungan sosial:
1) Dukungan Emosi. Dukungan jenis ini meliputi ungkapan rasa empati, kepedulian dan perhatian terhadap individu. Biasanya dukungan ini diperoleh dari pasangan atau keluarga, seperti memberikan pengertian terhadap masalah yang sedang dihadapi mendengarkan keluhannya. Adanya dukungan ini akan memberikan rasa nyaman, kepastian, perasaan memiliki, dan dicintai kepada individu.

2) Dukungan Penghargaan. Dukungan ini terjadi melalui ungkapan positif atau penghargaan yang positif kepada individu, dorongan untuk maju atau persetujuan akan gagasan atau perasaan individu dengan orang lain. Biasanya dukungan ini diberikan oleh atasan dan rekan kerja. Dukungan jenis ini akan membangun perasaan berharga, kompeten, dan bernilai.

3) Dukungan Instrumental. Dukungan jenis ini meliputi bantuan secara langsung. Biasanya dukungan ini lebih sering diberikan oleh teman atau rekan kerja, seperti bantuan untuk menyelesaikan tugas yang menumpuk, meminjamkan uang untuk keperluan pekerjaan, dan bantuan lain yang dibutuhkan individu. Adanya dukungan ini menggambarkan tersedianya barangbarang (materi) atau adanya pelayanan dari orang lain yang dapat membantu individu dalam meyelesaikan masalahnya. Selanjutnya hal tersebut akan memudahkan individu untuk dapat memenuhi tanggung jawab dalam menjalankan perannya seharihari.

4) Dukungan Informasi. Dukungan jenis ini meliputi pemberian nasihat, saran, atau umpan balik kepada individu. 
Dukungan ini biasanya diperoleh dari sahabat, rekan kerja, atasan, atau seorang profesional seperti dokter atau psikolog. Adanya dukungan informasi, seperti nasihat atau saran yang diberikan oleh orang-orang yang pernah mengalami keadaan yang serupa akan membantu individu memahami situasi dan mencari alternatif pemecahan masalah atau tindakan yang akan diambil.

5) Dukungan Jaringan Sosial. Dukungan jaringan dengan memberikan perasaan bahwa individu adalah anggota dari kelompok tertentu dan memiliki minat yang sama. Rasa kebersamaan dengan anggota kelompok merupakan dukungan bagi individu yang bersangkutan.

\section{KERANGKA KONSEPTUAL PENELITIAN}

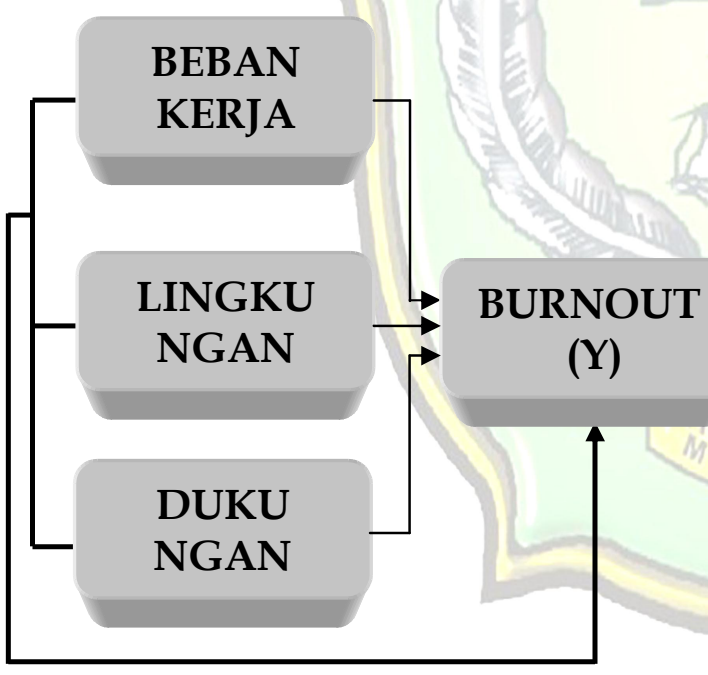

Keterangan :

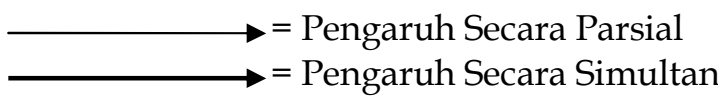

Gambar 1. Kerangka Konseptual Penelitian

\section{HIPOTESIS}

a) Beban Kerja, Lingkungan Kerja, dan Dukungan Sosial berpengaruh signifikan secara simultan terhadap Burnout pustakawan di Kota Mataram.

b) Beban Kerja, Lingkungan Kerja, dan Dukungan Sosial berpengaruh signifikan secara parsial terhadap Burnout pustakawan di Kota Mataram.

c) Beban Kerja mempunyai pengaruh paling dominan terhadap Burnout.

\section{METODE PENELITIAN}

\section{a. Jenis Penelitian}

Penelitian ini merupakan jenis penelitian asosiatif yaitu penelitian yang mengkaji hubungan dari satu variabel atau lebih terhadap variabel lainnya (Sugiyono, 2011:11). Penelitian ini berusaha menunjukkan bentuk pengaruh yang terjadi pada satu atau lebih variabel bebas terhadap variabel terikat dimana beban kerja, lingkungan kerja, dan dukungan sosial menjadi variabel bebas yang mempengaruhi burnout pustakawan yang dalam hal ini menjadi variabel terikatnya.

\section{b. Populasi dan Sampel Penelitian}

Populasi dalam penelitian ini adalah seluruh Pustakawan PNS yang ada di Kota Mataram yang tersebar di beberapa Perpustakaan Umum Pemerintah, Perpustakaan Perguruan Tinggi, dan Perpustakaan Sekolah yang berjumlah 76 orang pustakawan.

Sampel adalah sebagian dari populasi yang diteliti (Sugiyono, 2011). Sedangkan Arikunto (2012) menyatakan bahwa sampel adalah sebagian atau wakil populasi yang diteliti. Sampel yang digunakan dalam penelitian ini adalah 
sampel jenuh yang berarti bahwa seluruh anggota populasi diambil menjadi sampel. Jadi penelitiannya merupakan penelitian populasi. Hal ini sesuai dengan pendapat Sugiono (2007) yang menyatakan bahwa jika jumlah populasi kurang dari 100 maka sebaiknya diambil semua sebagai responden.

\section{c. Pengukuran Variabel}

Indikator masing-masing variabel dijabarkan dalam kuisioner dalam bentuk pernyataan. Kuisioner dirancang terstruktur menggunakan skala likert dengan alternatif jawaban yang tersedia, diberi skor sebagai berikut :

$$
\begin{array}{lll}
\text { SS } & =\text { Sangat Setuju } & \text { :Skor } 5 \\
\text { S } & =\text { Setuju } & \text { :Skor } 4 \\
\mathrm{R} & =\text { Ragu-ragu } & \text { Skor } 3 \\
\text { TS } & =\text { Tidak Setuju } & \text { :Skor } 2 \\
\text { STS } & =\text { Sangat Tidak Setuju } & \text { :Skor } 1
\end{array}
$$

\section{HASIL DAN PEMBAHASAN}

\section{a. Uji Asumsi Klasik}

Berdasarkan pada alat analisis yang digunakan pada penelitian ini, yaitu analisis regresi linier berganda, maka analisis dapat dilakukan dengan pertimbangan tidak adanya pelanggaran terhadap asumsi-asumsi klasik, yaitu normalitas, multikolinieritas, autokorelasi dan heteroskedastisitas (Suliyanto, 2005). lingkungan kerja, dan dukungan sosial terhadap burnout diatas 0.0001 dan memiliki VIF dibawah 5, yang berarti bahwa model regresi yang digunakan tidak terdapat problem multikolinieritas.

Tabel 1. Hasil Uji Multikolinieritas

\begin{tabular}{|c|c|c|}
\hline \multirow{2}{*}{ Model } & \multicolumn{2}{|c|}{ Collinearity Statistic } \\
\cline { 2 - 3 } & Tolerance & VIF \\
\hline Beban Kerja & .978 & 1.023 \\
\hline Lingkungan Kerja & .902 & 1.108 \\
\hline Dukungan Sosial & .890 & 1.124 \\
\hline
\end{tabular}

(Sumber: Pengolahan data lampiran)

Berdasarkan tabel 4.1 diatas, dapat dilihat bahwa nilai VIF berada pada kisaran 0,10 sampai 10, maka dapat dikatakan antar variabel tidak terjadi multikolinieritas.

\section{c. Uji Heterokedastisitas}

Uji ini dilakukan untuk menganalisa apakah dalam sebuah model regresi terjadi ketidaksamaan varians residual dari satu pengamatan ke pengamatan yang lain. Berdasarkan gambar di bawah memperlihatkan tidak adanya pola yang jelas, titik-titik menyebar di atas dan di bawah angka 0 pada sumbu Y. Hal ini berarti, tidak terjadi heteroskedastisitas pada model regresi, sehingga bisa disimpulkan bahwa model regresi tersebut layak digunakan untuk memprediksi generalisasi berdasarkan pada masukan variabel independennya.

\section{b. Uji Multikolinieritas}

Uji ini dilakukan untuk mengetahui apakah pada model regresi yang dihasilkan ditemukan adanya korelasi antar variable independen. Berdasarkan tabel 4.1 , terlihat bahwa nilai toleransi masing-masing variable beban kerja, 


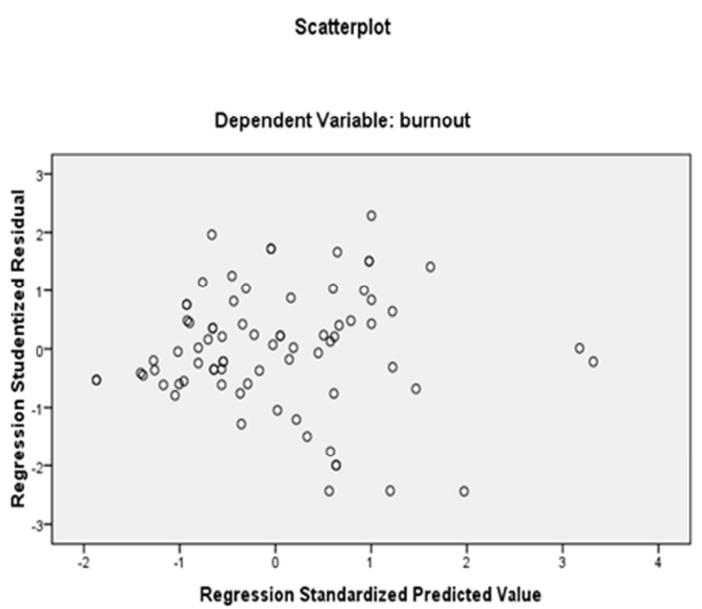

Gambar 2. Hasil Uji Heterokedastisitas

\section{d. Uji Autokorelasi}

Asumsi lain yang harus dipenuhi adalah tidak ada korelasi antara anggota serangkaian residual. Untuk mendeteksi apakah antar residual dalam model mempunyai hubungan yang linear, digunakan statistik uji Durbin Watson. Tabel 4.2. berikut menunjukan hasil uji autokorelasi.

Tabel 2. Hasil Uji Autokorelasi

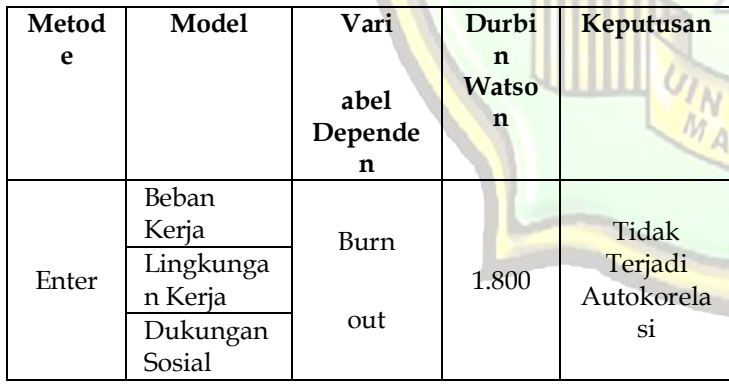

(Sumber: Pengolahan Data Lampiran)

Berdasarkan Tabel 2. di atas, terlihat bahwa model persamaan regresi yang dihasilkan, memperlihatkan angka D-W berada diantara -2 sampai dengan +2 , ini berarti bahwa model regresi tersebut tidak terdapat masalah autokorelasi.

\section{UJI HIPOTESIS}

\section{a. Uji F}

Uji F menyatakan bahwa beban kerja, lingkungan kerja, dan dukungan sosial berpengaruh signifikan secara simultan terhadap burnout pustakawan di Kota Mataram terbukti. Hal ini dilihat berdasarkan hasil pengolahan data yang ditampilkan pada tabel 4.3, dimana secara simultan dapat dilihat dari nilai $\mathrm{f}$ hitung $>$ $\mathrm{f}$ tabel (f hitung 52,045 $>\mathrm{f}$ tabel dengan $\alpha$ $0,05=2,732)$. Karena nilai $\mathrm{f}$ hitung $>\mathrm{f}$ tabel atau tingkat signifikansi $<0,05$, maka Ho ditolak dan Ha diterima. Sehingga bisa dikatakan bahwa model regresi bisa digunakan untuk memprediksi burnout, atau dengan kata lain variabel beban kerja, lingkungan kerja, dan dukungan sosial secara bersama - sama berpengaruh signifikan terhadap burnout.

\section{Tabel 3.}

Hasil Uji F (Hasil Uji secara simultan Beban Kerja, Lingkungan kerja, dan Dukungan Sosial terhadap Burnout)

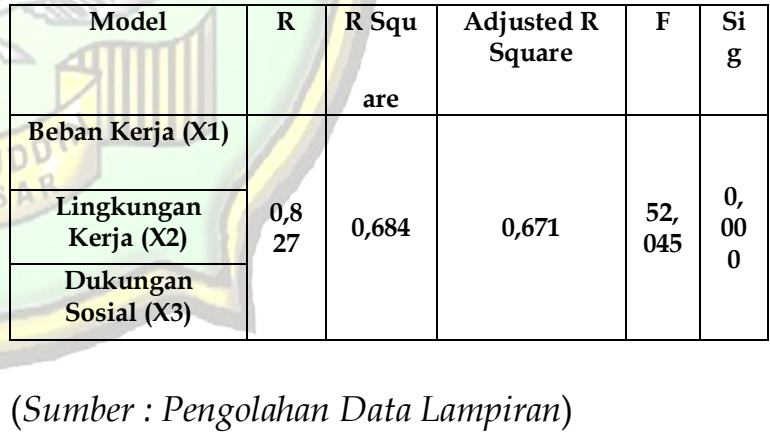

Hasil pengolahan dengan menggunakan program SPSS pada Tabel 3, menunjukkan bahwa $\mathrm{R}$ Square (Koefisien Determinasi) untuk model ini adalah 0,684, ini berarti 68,4\% burnout dapat dijelaskan oleh beban kerja, lingkungan kerja, dan dukungan sosial, 
sedangkan sisanya $(100 \%-68,4 \%=31,6 \%)$ dijelaskan oleh sebab - sebab lainnya.

\section{b. Uji T}

Uji T menyatakan bahwa beban kerja, lingkungan kerja, dan dukungan sosial berpengaruh signifikan secara parsial terhadap burnout pustakawan di Kota Mataram dapat dilihat dari hasil perhitungan regresi koefisien secara parsial dengan melihat $t$ hitung dan tingkat signifikansinya dari masing masing variabel bebas yaitu : Beban Kerja, Lingkungan Kerja, dan Dukungan Sosial terhadap Burnout, sebagaimana terlihat pada tabel 4.4 sebagai berikut :

Tabel 4.

Hasil Uji T Beban Kerja, Lingkungan Kerja, dan Dukungan Sosial terhadap Burnout

\begin{tabular}{|c|r|r|c|}
\hline Model & \multicolumn{1}{|c|}{$\begin{array}{c}\text { Koefisien } \\
\text { Regresi }\end{array}$} & T hitung & Sig \\
\hline Beban Kerja & .611 & 8.342 & 0,000 \\
\hline $\begin{array}{c}\text { Lingkungan } \\
\text { Kerja }\end{array}$ & -.122 & -2.156 & 0,034 \\
\hline $\begin{array}{c}\text { Dukungan } \\
\text { Sosial }\end{array}$ & -.358 & -6.647 & 0,000 \\
\hline Konstanta & 2,487 & 7,894 & 0,000 \\
\hline
\end{tabular}

(Sumber : Pengolahan Data Lampiran)

Berdasarkan pada Tabel 4. tersebut, maka persamaan regresi linier bergandanya adalah sebagai berikut:

\section{$\mathrm{Y}=2,487+0,611 \times 1-0,122 \times 2-0,358 \times 3+e$}

Interpretasi dari persamaan diatas adalah sebagai berikut:

1) Nilai Konstanta (a) $=2,487$ artinya jika variabel Beban Kerja (X1), Lingkungan Kerja (X2), dan Dukungan Sosial (X3) bernilai 0, maka Burnout (Y) bernilai positif yaitu sebesar 2,487.
2) Jika variabel Beban Kerja (X1) meningkat dengan asumsi variabel Lingkungan Kerja dan Dukungan Sosial tetap, maka Burnout juga akan meningkat.

3) Jika variabel Lingkungan Kerja (X2) meningkat dengan asumsi variabel Beban Kerja dan Dukungan Sosial tetap, maka Burnout akan menurun.

4) Jika variabel Dukungan Sosial (X3) meningkat dengan asumsi variabel Beban Kerja dan Lingkungan Kerja tetap, maka Burnout akan menurun.

Hasil perhitungan regresi linier berganda secara parsial pada Tabel 4 di atas dapat dijelaskan sebagai berikut ini:

1) Nilai koefisien regresi variabel Beban Kerja (X1) adalah sebesar 0,611. Artinya setiap perubahan yang terjadi pada Beban Kerja (X1) akan menyebabkan perubahan pada Burnout (Y) sebesar 0,611 dengan asumsi variabel lainnya tetap. Koefisien regresi yang bertanda positif menunjukkan pengaruh yang searah antara Beban Kerja (X1) dengan Burnout (Y). Nilai signifikan pada Beban Kerja (X1) sebesar 0,000. Nilai ini lebih kecil dari nilai signifikansi yang telah ditentukan sebesar 5\% $(0,05)$ maka dapat disimpulkan bahwa koefisien regresi untuk Beban Kerja (X1) berpengaruh signifikan terhadap Burnout (Y).

2) Nilai dari koefisien regresi untuk variabel Lingkungan Kerja (X2) adalah sebesar -0,122. Artinya jika variabel Lingkungan Kerja (X2) berubah satu satuan, maka Burnout (Y) akan berubah sebesar -0,122 dengan asumsi variabel lainnya tetap. Koefisien regresi yang bertanda negatif menunjukkan pengaruh yang tidak searah antara variabel Lingkungan 
Kerja (X2) terhadap Burnout (Y), artinya apabila variabel Lingkungan Kerja (X2) menurun maka Burnout (Y) akan meningkat dan sebaliknya. Nilai signifikan pada variabel X2 sebesar 0,034, Nilai ini lebih kecil dari nilai signifikansi yang telah ditentukan sebesar $5 \% \quad(0,05)$ maka dapat disimpulkan bahwa koefisien regresi untuk variabel Lingkungan Kerja (X2) berpengaruh signifikan terhadap variabel Burnout (Y).

3) Nilai koefisien regresi variabel Dukungan Sosial (X3) adalah sebesar 0,358 . Artinya jika variabel Dukungan Sosial (X3) berubah satu satuan, maka Burnout (Y) akan berubah sebesar 0,358 dengan asumsi variabel lainnya tetap. Koefisien regresi yang bertanda negatif menunjukkan pengaruh yang tidak searah antara variabel Dukungan Sosial (X3) dengan Burnout (Y), artinya apabila variabel Dukungan Sosial (X3) menurun maka Burnout (Y) akan meningkat dan sebaliknya. Nilai signifikan pada variabel $\mathrm{X} 3$ sebesar 0,000. Nilai ini lebih kecil dari nilai signifikansi yang telah ditentukan sebesar $5 \% \quad(0,05)$ maka dapat disimpulkan bahwa koefisien regresi untuk variabel Dukungan Sosial (X3) berpengaruh signifikan terhadap variabel Burnout (Y).

4) Variable Beban Kerja, Lingkungan Kerja dan Dukungan Sosial secara parsial mempunyai pengaruh yang signifikan terhadap variabel Burnout.

\section{c. Uji Hipotesis Ketiga (Dominan Variabel)}

Hipotesis Ketiga menyatakan bahwa Beban Kerja (X1) berpengaruh dominan terhadap Burnout pustakawan di Kota Mataram. Untuk membuktikan hipotesis 3 dapat dilihat nilai thitung dan tingkat signifikansinya Untuk lebih jelasnya dapat dilihat pada Tabel 4.

Dari hasil pengujian model regresi variable Beban Kerja (X1) mempunyai

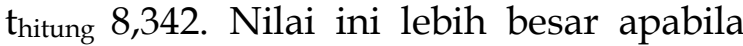
dibandingkan dengan variable Lingkungan Kerja (X2) dan Dukungan Sosial (X3), maka hipotesis yang menyatakan bahwa Beban Kerja berpengaruh dominan terhadap Burnout diterima.

Berdasarkan hasil analisis pengujian hipotesis, dapat dibuat ringkasan hipotesis yang diterima, seperti yang dapat dilihat pada Tabel 5. berikut ini:

Tabel 5.

Ringkasan Pengujian Hipotesis

\begin{tabular}{|c|l|l|l|}
\hline Hipo & \multicolumn{1}{|c|}{ Pernyatan } & Sig (p) & Keputusan \\
\hline tesis & $\begin{array}{l}\text { Bahwa beban } \\
\text { kerja, } \\
\text { lingkungan } \\
\text { kerja, dan } \\
\text { dukungan sosial } \\
\text { secara simultan } \\
\text { berpengaruh } \\
\text { signifikan } \\
\text { terhadap } \\
\text { burnout. }\end{array}$ & $\begin{array}{l}\text { Bahwa beban } \\
\text { kerja, } \\
\text { lingkungan } \\
\text { kerja, dan } \\
\text { dukungan sosial } \\
\text { secara parsial } \\
\text { berpengaruh } \\
\text { signifikan } \\
\text { terhadap } \\
\text { burnout. }\end{array}$ & $\begin{array}{l}\text { Bahwa variabel } \\
\text { Beban Kerja } \\
\text { berpengaruh } \\
\text { dominan } \\
\text { terhadap } \\
\text { burnout. }\end{array}$ \\
\hline 2 & 0.034 & Diterima \\
\hline 3 & 0.000 & Diterima \\
\hline
\end{tabular}

(Sumber : Pengolahan Data Lampiran) 


\section{PEMBAHASAN}

\section{a. Pembahasan Data Deskriptif Variabel Beban Kerja}

Rata-rata nilai variabel beban kerja pada penelitian ini adalah 3,39. Nilai ini menunjukkan bahwa rata-rata tanggapan pustakawan di Kota Mataram menyetujui bahwa beban kerja yang dipikul mereka berada pada tingkat sedang namun cukup sejalan dengan nilai-nilai yang dimiliki oleh organisasi. Berdasarkan pada nilai rata-rata variabel beban kerja dapat disimpulkan bahwa rata-rata pustakawan di Kota Mataram merasakan bahwa beban kerja yang berada pada tingkat sedang juga dapat mempengaruhi burnout mereka dalam organisasi.

\section{b. Pembahasan Data Deskriptif Variabel Lingkungan Kerja}

Rata-rata nilai variabel beban kerja pada penelitian ini adalah 2,38. Nilai ini menunjukkan bahwa rata-rata tanggapan pustakawan di Kota Mataram menyetujui bahwa lingkungan kerja di lembaga perpustakaan tersebut kurang memadai seperti kondisi lingkungan yang kurang nyaman, aman dan kurang menyenangkan, sehingga karyawan tidak dapat melakukan aktivitas kerja dengan penuh semangat dan merasa terbebani sehingga hal itu akan mempengaruhi burnout pustakawan. Lingkungan kerja akan dapat mempengaruhi burnout pustakawan, dimana suasana kerja yang kondusif akan menurunkan tingkat burnout pustakawan dan sebaliknya suasana kerja yang tidak selaras dengan kebutuhan pustakawan akan dapat menimbulkan tingginya tingkat burnout.

\section{c. Pembahasan Data Deskriptif Variabel Dukungan Sosial}

Rata-rata variabel dukungan sosial pada penelitian ini menunjukkan angka 2,48, ini berarti rata-rata para pustakawan di Kota Mataram menganggap bahwa dukungan yang diberikan rekan kerja dan atasan berupa perhatian, empati, dorongan untuk maju, persetujuan gagasan, bantuan bahan kerja, bantuan kerja, pemberian nasihat, pemberian umpan balik, pengakuan eksistensi, dan kebersamaan dalam kelompok masih belum memadai sehingga diperlukan peningkatan untuk mengurangi potensi peningkatan level burnout. Nilai ini menunjukkan bahwa dukungan sosial yang ada pada organisasi perpustakaan di Kota Mataram berada pada level rendah.

\section{d. Pembahasan Data Deskriptif Variabel Burnout}

Variabel burnout yang digunakan dalam penelitian ini menitik beratkan pada suatu keadaan yang bersifat internal, yang bisa disebabkan oleh tuntutan fisik, atau lingkungan, dan situasi sosial yang berpotensi merusak dan tidak terkontrol yang pada intinya sangat dipengaruhi oleh tingkat beban kerja, kondisi lingkungan kerja dan dukungan sosial di tempat kerja. Namun jika dilihat dari hasil jawaban pada kuesioner yang diberikan menunjukkan nilai burnout pada level sedang, yaitu $(3,38)$. Hal ini menunjukkan bahwa para pustakawan di Kota Mataram, merasa adanya gangguan baik dari segi fisik maupun psikologi mereka sebagai akibat dari adanya burnout yang mereka dapatkan yang dimungkinkan sebagai akibat adanya beban kerja yang tinggi, lingkungan kerja yang tidak memadai dan dukungan sosial yang rendah. 


\section{e. Pembahasan Hasil Analisis Penelitian}

1. Pengaruh beban kerja, lingkungan kerja, dan dukungan sosial terhadap burnout secara simultan

Secara bersama-sama (simultan) hasil penelitian ini menunjukkan bahwa variabel beban kerja, lingkungan kerja, dan dukungan sosial mempunyai pengaruh signifikan terhadap burnout pustakawan. Hal ini berarti bahwa burnout pustakawan di Kota Mataram dipengaruhi oleh beban kerja, lingkungan kerja, dan dukungan sosial. Artinya pustakawan di Kota Mataram merasa beban kerja mereka berada pada level sedang, lingkungan kerja tidak memadai serta dukungan sosial yang rendah yang berakibat pada tingkat burnout pustakawan yang berada pada level sedang.

Hal ini disebabkan karena pustakawan di Kota Mataram secara umum masih merasa mendapatkan beban kerja dengan level sedang, lingkungan kerja yang tidak memadai serta dukungan sosial yang rendah. Indikasi bahwa pustakawan mendapatkan beban kerja dengan level sedang serta lingkungan kerja yang tidak memadai dan dukungan sosial yang rendah terlihat dari gejala-gejala burnout yang dimunculkan. Dalam melaksanakan tugas kesehariannya para pustakawan di Kota Mataram menyelesaikan tugas belum maksimal, belum memenuhi target yang telah ditetapkan lembaga perpustakaan sesuai dengan cara dan aturan yang berlaku, disiplin yang masih rendah misalnya dilihat dari tingkat absensi yang tinggi, selain itu setiap pustakawan juga belum mengetahui dengan baik tugas dan tanggung jawab yang telah dibebankan kepada mereka. Dalam hubungan kerjasama antara karyawan dengan atasan selama ini terjalin kurang harmonis yang sering ditunjukkan dengan saling tumpang tindih dalam menyelesaikan pekerjaan dan menjalin komunikasi yang belum baik sehingga sering timbul masalah.

Jika dikaji secara parsial variabel beban kerja, lingkungan kerja, dan dukungan sosial masing-masing mempunyai pengaruh yang signifikan terhadap burnout. Artinya burnout pustakawan di Kota Mataram disebabkan karena beban kerja dengan level sedang, lingkungan kerja yang tidak memadai serta dukungan sosial yang rendah.

2. Pengaruh beban kerja, lingkungankerja, dan dukungan sosial terhadap burnout secara simultan

Adapun uraian secara parsial pengaruh beban kerja, lingkungan kerja, dan dukungan sosial dapat dijabarkan sebagai berikut:

\section{Beban Kerja (X1)}

Beban Kerja mempunyai pengaruh signifikan terhadap Burnout. Beban Kerja dicirikan sebagai sejumlah kegiatan, waktu, dan energi yang harus dikeluarkan seseorang baik fisik ataupun mental dengan memberikan kapasitas mereka untuk memenuhi tuntutan tugas yang diberikan. Para pustakawan merasa beban kerja yang mereka pertanggung jawabkan telah melebihi kemampuan dan kapasitas mereka.Hal ini sesuai dengan pendapat Togia (2005) dalam Mizmir (2011 : 2) yang menyatakan bahwa banyak aspek di lingkungan kerja pustakawan yang telah diidentifikasi sebagai sumber potensial dari stress dan yang mempunyai hubungan erat dengan burnout. Adapun sumber tersebut antara lain meliputi beban kerja yang berlebihan, kurangnya 
pengetahuan atau keahlian untuk melakukan pekerjaan, tugas-tugas yang rutin dan berulang, interaksi dengan pengunjung perpustakaan dan staf, tidak adanya rasa hormat dan penghargaan dari atasan, dan fakta bahwa pada kondisi nyata pekerjaan tidak mencukupi harapan pekerja.

Sedangkan menurut pendapat Maslach (1982) dalam Hariyadi (2006 : 68) menyatakan bahwa beban kerja staf perpustakaan meliputi jam kerja yang panjang dan banyaknya jumlah individu yang harus dilayani menyebabkan staf perpustakaan merasa mempunyai beban kerja yang harus dipikul. Hal ini merupakan faktor pemicu stress yang potensial menjadi penyebab burnout pada staf perpustakaan. Pengaruh beban kerja terhadap kecenderungan burnout juga telah diteliti oleh Fatmawati (2012) dengan subjek penelitian pada staf perpustakaan yang menunjukkan hasil terdapat korelasi positif antara beban kerja terhadap tingkat burnout. Selain itu penelitan yang dilakukan oleh Solikhah (2012) dengan subjek penelitian pada perawat, Maharani (2012) dengan subjek penelitian pada perawat, dan Verdugo (2013) dengan subjek penelitian pada perawat juga sejalan dengan hasil penelitian ini dimana beban kerja berpengaruh positif terhadap burnout. Hal ini menunjukkan bahwa hasil penelitian ini sudah sesuai dengan beberapa penelitian terdahulu yang meneliti variabel beban kerja terhadap tingkat burnout.

\section{$\checkmark$ Lingkungan Kerja (X2)}

Variabel lingkungan kerja secara statistik berpengaruh secara negatif dan signifikan terhadap burnout pustakawan. Hal ini menandakan bahwa lingkungan kerja mempunyai pengaruh yang tidak searah terhadap burnout. Artinya penurunan kondisi lingkungan kerja akan berpengaruh pada peningkatan tingkat burnout pustakawan, demikian pula sebaliknya apabila kondisi lingkungan kerja semakin memadai maka tingkat burnout akan mengalami penurunan. Hal ini sesuai dengan pendapat Kartono (1994) dalam Khotimah (2010 : 10) yang menyatakan bahwa lingkungan kerja merupakan faktor penting dan berpengaruh terhadap karyawan dalam melaksanakan pekerjaannya. Lingkungan kerja sangat mempengaruhi keadaan karyawan dalam bekerja, dimana lingkungan kerja yang buruk akan menyebabkan timbulnya kelelahan, ketegangan emosi, serta motivasi yang rendah. Sebaliknya lingkungan kerja yang baik menciptakan motivasi tinggi dan tidak menimbulkan kelelahan serta ketegangan emosi pada karyawan.

Pengaruh lingkungan kerja terhadap kecenderungan burnout juga telah diteliti oleh Andriani (2004 : 61) dengan subjek penelitian pada perawat yang menunjukkan hasil terdapat korelasi negatif antara kondisi lingkungan kerja terhadap kecenderungan burnout. Penelitian yang dilakukan Fahri (2010) dengan subjek penelitian pada staf bagian drilling dan Husein (2011) dengan subjek penelitian pada staf bagian produksi juga menemukan hal yang sama. Hal ini menunjukkan bahwa hasil penelitian ini sudah sesuai dengan beberapa penelitian terdahulu yang meneliti variabel lingkungan kerja terhadap kecenderungan burnout.

\section{$\checkmark$ Dukungan Sosial (X3)}

Variabel dukungan sosial secara statistik berpengaruh secara negatif dan 
signifikan terhadap burnout pustakawan. Hal ini menandakan bahwa dukungan sosial mempunyai pengaruh yang tidak searah terhadap burnout. Artinya penurunan tingkat dukungan sosial akan berpengaruh pada peningkatan tingkat burnout pustakawan, demikian pula sebaliknya apabila tingkat dukungan sosial semakin tinggi maka tingkat burnout akan mengalami penurunan. Hal ini sesuai dengan pendapat Sarafino (2006) yang menyatakan bahwa adanya dukungan sosial membuat individu merasa yakin dirinya dicintai dan dihargai sehingga dapat mengurangi gejala burnout yang dialaminya. Sebaliknya, tidak adanya dukungan sosial dapat menimbulkan ketegangan dan meningkatkan terjadinya burnout pada individu.

Hasil penelitian Purba (2007) dengan subjek penelitian pada guru juga menunjukkan pengaruh yang negatif antara dukungan sosial terhadap burnout. Penelitian yang dilakukan oleh Labiib (2013) dengan subjek penelitian pada perawat juga menemukan hal yang sama dimana dukungan sosial dari rekan kerja dan atasan memiliki pengaruh yang negatif dan signifikan terhadap burnout. Semakin tinggi dukungan yang diterima maka burnout akan semakin rendah. Selain itu penelitian yang dilakukan oleh Wardhani (2012) dengan subjek penelitian pada guru pendidikan luar biasa, Nugroho (2012) dengan subjek penelitian pada perawat, dan Shropshire (2012) dengan subjek penelitian pada staf bagian IT (Information and Technology) juga menemukan hal yang sama. Hal ini berarti bahwa hasil penelitian ini sudah sesuai dengan beberapa penelitian terdahulu yang meneliti variabel dukungan sosial terhadap kecenderungan burnout.

\section{Variabel Berpengaruh Paling Dominan Terhadap Stres Kerja}

Berdasarkan hasil analisis regresi yang dilakukan dapat disimpulkan bahwa variabel beban kerja merupakan variabel yang paling dominan mempengaruhi burnout. Hasil analisis ini sesuai dengan teori yang dikemukakan oleh T. Hani Handoko (2001:193) mengungkapkan bahwa kondisi kerja yang sering menyebabkan stres bagi karyawan adalah beban kerja yang berlebihan. Sedangkan menurut Leither \& Maslach (2005) stress berkepanjangan yang dialami individu yang pekerjaannya berhadapan secara langsung dengan manusia sebagai penerima pelayanan disebut burnout. Hal ini dikarenakan faktor dari beban kerja yang sangat beragam dan erat kaitannya dengan pustakawan sebagai pekerja pelayanan informasi. Adanya penelitian terdahulu yang juga menyimpulkan bahwa variabel beban kerja mempunyai pengaruh terhadap burnout semakin memperkuat hasil penelitian ini.

\section{KESIMPULAN DAN SARAN}

\section{a. Kesimpulan}

Berdasarkan hasil kajian setelah menguji dan menganalisis pengaruh beban kerja, lingkungan kerja, dan dukungan sosial terhadap burnout selanjutnya dapat ditarik kesimpulan sebagai berikut:

1) Secara parsial variabel beban kerja berpengaruh positif dan signifikan terhadap burnout pustakawan di Kota Mataram. Hal ini dapat dilihat dari nilai $\mathrm{t}$ hitungnya sebesar 8,342 lebih besar dari nilai $\mathrm{t}$ table sebesar 1,993 dengan probabilitas signifikansi 0,000 $<0,05$. Sedangkan variabel lingkungan kerja dan dukungan sosial secara 
parsial berpengaruh negatif dan signifikan terhadap burnout pustakawan di Kota Mataram dengan nilai t hitung masing-masing 2,156 dan 6,647 lebih besar dari nilai $t$ table sebesar 1,993 dengan probabilitas signifikansi 0,000 <0,05.

2) Secara simultan variabel beban kerja, lingkungan kerja, dan dukungan sosial berpengaruh positif dan signifikan terhadap burnout pustakawan di Kota Mataram. Hal ini dapat dilihat dari hasil uji $\mathrm{F}$ dimana $\mathrm{F}$ hitung $>\mathrm{F}$ tabel $(52,045>2,732)$.

3) Variabel beban kerja merupakan variabel yang paling dominan mempengaruhi burnout pustakawan di Kota Mataram, terbukti dengan nilai $t$ hitung lebih besar dari nilai $t$ hitung pada variabel lingkungan kerja dan dukungan sosial.

\section{b. Saran}

Berdasarkan simpulan hasil penelitian, selanjutnya disampaikan saran, baik untuk kepentingan sebagai praktisi maupun untuk kepentingan penelitian selanjutnya :

1) Untuk menghindarkan pustakawan dari burnout berdasarkan jawaban responden diketahui bahwa indikator yang paling banyak berpengaruh pada tingginya beban kerja adalah giliran kerja (shift) yang belum dikelola secara baik sehingga pihak atasan dan pustakawan sendiri perlu untuk tetap melakukan evaluasi secara berkala untuk menemukan solusi dari masalah tersebut antara lain dengan melakukan pengundian giliran kerja sehingga semua pustakawan mendapatkan giliran kerja secara adil.

2) Berdasarkan jawaban responden pada variabel lingkungan kerja diketahui bahwa indikator yang paling rendah adalah pada peralatan alat tulis kantor seperti printer, komputer, dan lain-lain sehingga disarankan agar pihak manajemen perpustakaan untuk melakukan evaluasi pengadaan terhadap kebutuhan pustakawan akan peralatan alat tulis kantor yang memadai di tempat kerja.

3) Berdasarkan jawaban responden pada variabel dukungan sosial diketahui bahwa indikator yang paling rendah adalah indikator kebersamaan dengan kelompok sehingga diperlukan acaraacara gathering atau outbond yang dapat meningkatkan rasa kebersamaan dengan kelompok dalam organisasi perpustakaan.

4) Berdasarkan jawaban responden terhadap variabel burnout diketahui bahwa indikator yang paling tinggi adalah pada gairah bekerja sehingga disarankan pada pihak manajemen perpustakaan negeri di Kota Mataram untuk melakukan desain ulang pekerjaan ataupun menambah variasi jenis pekerjaan, memberikan penghargaan dan kompensasi lebih terhadap prestasi kerja sehingga dapat meningkatkan semangat kerja pustakawan.

5) Mengingat faktor beban kerja menjadi variabel yang menentukan terhadap burnout diperlukan adanya rotasi, mutasi, dan promosi yang dilakukan secara berkala dan proporsional untuk menghindari terjadinya burnout.

6) Perlu adanya perhatian lebih dari instansi terkait dalam penentuan beban kerja yang diberikan kepada pustakawan pada Perpustakaan Negeri di Kota Mataram.

7) Disarankan kepada para peneliti selanjutnya untuk meneliti faktorfaktor lain yang mempengaruhi burnout pustakawan di Kota Mataram 
seperti motivasi, kompensasi, persepsi, kepercayaan, keinginan, kepuasan kerja, emosi pekerja, fisik pekerja, dan lain-lain.

\section{DAFTAR PUSTAKA}

Andriani, R. (2004), "Pengaruh Persepsi Mengenai Kondisi Lingkungan Kerja dan Dukungan Sosial Terhadap Tingkat Burnout pada perawat IRD RSUD dr. Soetomo Surabaya", Jurnal Insan, Oktober, Vol.6, No. 1. 101-112.

Fahri, S. \& Pasha, E. (2010), “Kebisingan dan Tekanan Panas dengan Perasaan Kelelahan Kerja pada Tenaga Kerja Bagian Drilling Pertamina EP Jambi", Jurnal Unimus Jambi, Vol.2, No. 1, Desember, 128-136.

Fatmawati, R. (2012), Burnout Staf Perpustakaan Bagian Layanan di Badan Perpustakaan dan Arsip Daerah (BPAD) Provinsi DKI Jakarta, Thesis, Jakarta : Fakultas Ilmu Budaya Universitas Indonesia.

Gehmeyr, A. (2000), “WorterklaerungenBurnout", tersedia di www.fmi.unipassu.de/worterklaerungen/burnou t.html. (Diakses 20 September 2013).

Hariyadi, U. (2006), Burnout pada Pustakawan : Perpustakaan dan Informasi dalam Konteks Budaya. Depok : Universitas Indonesia.

Hasibuan, M. S. P. (2009), Manajemen Sumber Daya Manusia, Jakarta : Bumi Aksara.

Husein, T. \& Sarsono, A. (2011), "Perancangan Sistem Kerja Ergonomis untuk Mengurangi Tingkat Kelelahan Kerja", Jurnal Teknologi Industri Universitas Mercubuana Jakarta, Vol. 1, No.1, 1-18. Ilyas, A. (2012), “Kejenuhan Kerja dan Upaya Mengatasinya Dalam Rangka Meningkatkan Kinerja Pegawai", tersedia http:/ / butuhkerjaa.blogspot.com.

(Diakses 25 Desember 2013).

Karatepe. \& Osman, M. (2010), “Work Family Conflict and Burnout in Frontline Service Jobs : Direct, Mediating, and moderating Effects", tersedia

di http://www.faqs.org/periodicals/2 01010/ 2217813431.html\#ixzzlheKqTTSp.

(Diakses 28 Desember 2013).

Khotimah, K. (2010), “Hubungan antara Persepsi terhadap Lingkungan Kerja Psikologis dengan Burnout pada Perawat RSU Budi Rahayu Pekalongan", Jurnal Psikologi Universitas Diponegoro Semarang, Vol. 6, No. 1, 7-12.

Kurniawati, D., \& Solikhah. (2012), "Hubungan kelelahan kerja dengan kinerja perawat di bangsal rawat inap rumah sakit islam fatimah kabupaten cilacap", Jurnal Kesehatan Masyarakat Universitas Ahmad Dahlan (UAD) Yogyakarta, Vol. 6, No. 2, 162 232.

Labiib, A. (2013), "Analisis Hubungan Dukungan Sosial dari Rekan Kerja dan Atasan dengan Tingkat Burnout pada Perawat Rumah Sakit Jiwa", Jurnal Kesehatan Masyarakat Universitas Diponegoro Semarang, Vol. 2, No. 1, 1-8.

Lazarus, R. \& Folkman, S. (1984), Stress, Appraisal, and Coping, New York : Springer.

Leither, M. \& Maslach, C. (2005), Vanishing Burnout : Six Strategies For Improving Your Relationship With Work, United States of America : Jossey-Bass.

Maharani, P. A. (2012), “Kejenuhan Kerja (Burnout) dengan Kinerja Perawat dalam Pemberian Asuhan Keperawatan", Jurnal Kesehatan STIKES RS Baptis Kediri, Vol. 5, No. 2, Desember, 167-178. 
Mizmir. (2011), Hubungan Burnout dengan Kepuasan Kerja Pustakawan di Pusat Jasa Perpustakaan dan Informasi Perpustakaan Nasional Republik Indonesia,Skripsi, Jakarta : Fakultas Ilmu Pengetahuan Budaya Universitas Indonesia.

Nasution, M. (1994), Manajemen Personalia, Jakarta : Djambatan.

Nitisemito, A. S. (1996), Manajemen Personalia : Manajemen Sumber Daya Manusia, Cetakan ke-9, Jakarta : Ghalia Indonesia.

Nitisemito, A. S. (2004), Manajemen Sumber Daya Manusia dan Organisasi, Jakarta : Unipress.

Nugroho, A. S. (2012), "Studi Deskriptif Burnout dan Coping Stress pada Perawat di Ruang Rawat Inap Rumah Sakit Jiwa Menur Surabaya", Jurnal Ilmiah Mahasiswa Universitas Surabaya, Vo. 1, No. 1, 1-6.

Nurmianto, E. (1996), Ergonomi konsep Dasar dan Aplikasinya, Semarang : ITSN.

Notoatmodjo, S. (2009), Pengembangan Sumber Daya Manusia, Jakarta : Rhineka Cipta.

Ogden, J. (2004), Health psychology: A Textbook. (3 ${ }^{\text {rd }}$ Ed.), Open University Press, McGraw-Hill Education England.

Poerwandari, K. (2010), Mengatasi Burnout di Tempat Kerja. http://www.portalhr..com.tips/2id2 23.html. Diakses pada 19 September 2013.

Priyatno, D. (2009), 5 Jam Belajar Olah Data dengan SPSS 17, Yogyakarta : Penerbit ANDI.

Purba, J., Yulianto, A., \& Widyanti, E. (2007), "Pengaruh Dukungan Sosial terhadap Burnout pada Guru", Jurnal Psikologi Universitas Indonusa Esa Unggul, Vol. 5, No. 1, 77-87.
Robbins, S. P. (2003), Organizational Behaviour Concept, Controversiest Applications, $6^{\text {th }}$ Ed., Eaglewood Cliff, New Jersey : Prentice Hall, Inc.

Sarafino, E. P. (2006), Health Psychology : Biopsychocial Interactions. $4^{\text {th }} \mathrm{Ed}$., New Jersey : John Wiley \& Sons Inc.

Sedarmayanti. (2007), Sumber Daya Manusia dan Produktifitas Kerja, Bandung : Penerbit Mandar Maju.

Setyawati, LM. (2010), Selintas tentang kelelahan Kerja, Yogyakarta : Amara Books.

Shaw, J.B., \& Weekly, J.A. (1985), “The Effect of Objective Workload Variations of Psycological Strain and Postwork Load Performance", Journal of Management, XI(1), 97-108.

Shropshire, J. \& Kadlec, C. (2012), “I'm Leaving The IT Field : The Impact of Stress, Job Insecurity, and Burnout on IT Professionals", International Journal of Information and Communication Technology Research, Vol. 2, No.1, 6-16.

Smith, Gill \& Segal, J. (2008), "Stress : Preventing Burnout", http://www.chinaconsult.com.au/2009/11/20/3240/ (Diakses 18 September 2013).

Soleman, A., \& Sitania, F.,D. (2011), "Pedoman Kesehatan dan Keselamatan Kerja pada Industri Kerajinan Kerang Mutiara", Jurnal ARIKA, Vol. 05, No. 2, Agustus, 125136.

Solikhah, D.W. (2012), “Hubungan Kelelahan Kerja dengan Kinerja Perawat di bangsal Rawat Inap Rumah Sakit Islam Fatimah Kabupaten Cilacap", Jurnal Kesehatan Masyarakat Universitas Diponegoro Semarang, Vol. 6, No. 2, 162-232.

Sugiono. (2007), Metode Penelitian Administrasi, Bandung : Alfabeta. 
Sugiyono. (2011), Metode Penelitian Kuantitatif Kualitatif dan RED, Bandung: Alfabeta.

Suliyanto. (2005), Analisis Data dalam Aplikasi Pemasaran, Bogor : Ghalia Indonesia.

Suma'mur, P.,K. (1995), Ergonomi untuk Produktivitas Kerja, Jakarta : Gunung Agung.

Verdugo, A. \& Patricia, L. (2013), "Prevalence of Burnout Syndrome in Nursing Staff of a Third Level Hospital Boyaca Colombia", Journal of Enfermeria Global Universidad de Murcia Colombia, Vol. 1, No. 29, 89104.

Wardhani, D.T. (2012), "Burnout di Kalangan Guru Pendidikan Luar Biasa di Kota Bandung", Jurnal Psikologi Universitas Diponegoro Semarang, Vol. 11, No.1, 73-82.

Wulandari, S., A. (2013), "Persepsi Dukungan Sosial Rekan Kerja dengan Burnout pada Teller Bank", Jurnal Online Psikologi Universitas Muhammadiyah Malang, Vol. 01, No. 02, 503-514.

Zagladi, A.L. (2004), Pengaruh Kelelahan Emosional Terhadap Kepuasan Kerja dan Kinerja Dalam Pencapaian Komitmen Organisasional Dosen Perguruan Tinggi Swasta, Disertasi, Program Doktor Manajemen, Program Pascasarjana Fakultas Ekonomi Universitas Brawijaya Malang.

(2004), Keputusan Menteri Pendayagunaan Aparatur Negara No. $\quad$ 132/Kep/Menpan/12/2002 tentang Jabatan Fungsional Pustakawan dan Angka Kreditnya. Jakarta : Perpustakaan Nasional Republik Indonesia. . (2007), UU Nomor 43 Tahun 2007 tentang Perpustakaan. Jakarta : Perpustakaan nasional RI.
- (2011), Peraturan Kepala Perpustakaan Nasional Republik Indonesia Nomor 2 Tahun 2008 tentang Petunjuk Teknis Jabatan Fungsional Pustakawan dan Angka Kreditnya. Jakarta : Perpustakaan Nasional RI. 